\title{
Mountain weather and climate: A general overview and a focus on climatic change in the Alps
}

\author{
Martin Beniston \\ Department of Geosciences, University of Fribourg, Chemin du Musée 4, CH-1700 Fribourg, Switzerland \\ (E-mail: Martin.Beniston@Unifr.ch)
}

Key words: climatic change, climate impacts, Alps

\begin{abstract}
Meteorological and climatic processes in mountain regions play a key role in many environmental systems, in particular the quantity and quality of water that influences both aquatic ecosystems and economic systems often far beyond the boundaries of the mountains themselves. This paper will provide a general overview of some of the particular characteristics of mountain weather and climate, to highlight some of the unique atmospheric features that are associated with regions of complex topography. The second part of the paper will focus upon characteristics of climate and climatic change in the European Alps, a region with a wealth of high quality data that allows an assessment on how climate and dependent environmental systems have evolved in the course of the 20th century and how alpine climate may undergo further changes to "global warming" in the 21 st century, as the atmosphere responds to increasing levels of greenhouse gases that are expected in coming decades.
\end{abstract}

\section{Introduction}

Significant orographic features occupy close to $25 \%$ of continental surfaces (Kapos et al., 2000) and, although only about $26 \%$ of the world's population resides within mountains or in the foothills of the mountains (Meybeck et al., 2001), mountain-based resources indirectly provide sustenance for over half. Moreover, $40 \%$ of global population lives in the watersheds of rivers originating in various mountains of the world. Although mountains differ considerably from one region to another, one common characteristic is the complexity of their topography. Orographic features include some of the sharpest gradients found in continental areas. Related characteristics include rapid and systematic changes in climatic parameters, in particular temperature and precipitation, over very short distances (Becker \&
Bugmann, 1997). Since climate changes rapidly with height over relatively short horizontal distances, so does vegetation and hydrology (Whiteman, 2000). As a consequence, mountains exhibit high biodiversity, often with sharp transitions (ecotones) in vegetation sequences, and equally rapid changes from vegetation and soil to snow and ice. In addition, mountains ecosystems are often endemic, because many species remain isolated at high elevations compared to lowland vegetation communities that can occupy climatic niches spread over wider surface areas. Certain mountain chains have been referred to as "islands" rising above the surrounding plains (Hedberg, 1964), such as those in East Africa. As climate exerts a fundamental control on many biological, physical and chemical systems in mountains, it is of interest to assess the characteristics of regional climate in regions such as the Alps, and how these 
climates may change in the future in response to human activities. Indeed, mountains are susceptible to the impacts of a rapidly changing climate, and provide interesting locations for the early detection and study of the signals of climatic change and its impacts on hydrological, ecological, and societal systems (Beniston, 2003).

\section{Climate processes in mountain regions}

Mountain climates are governed by four major factors (Barry, 1994), namely continentality, latitude, altitude, and topography. The relative influences of these factors will be briefly summarized in this section.

\section{Geographical controls on mountain climates}

Continentality refers to the proximity of a particular region to an ocean. The diurnal and annual ranges of temperatures in a maritime climate are markedly less than in regions far removed from the oceans; this is essentially due to the large thermal capacity of the sea, which warms and cools far less rapidly than land. Since the ocean represents a large source of moisture, there is also more precipitation in a maritime climate than in a continental one, provided the dominant wind direction is onshore. Examples of maritime mountain climates include the Cascade Ranges in Oregon and Washington States of the US, the Alaskan coastal mountains, the New Zealand Alps, the Norwegian Alps, and the southern Chilean Andes. Mountains under the dominant influence of continental-type climates include the Tibetan Plateau, the mountains of Central Asia (Pamir, Tien Shan, Urals), the Rocky Mountains in Colorado, Wyoming and Montana States of the US. However, many other mountain regions often define and separate climatic regions; in particular, the European Alps act as a boundary between Mediterranean-type, Atlantic, and continental climates.

While mountains in continental regions experience more sunshine, less precipitation, and a larger range of temperatures than maritime mountains, they are not necessarily harsher environments. For certain ecosystems, the larger amounts of sunshine compensate for lower mean temperatures in continental regions. Increased cloudiness and precipitation (both rain and snow) in coastal mountain ranges such as the Cascades or the New Zealand Alps limit the growth of certain species despite the milder overall temperatures. The timberline in continental regions is often located at higher elevations than in maritime zones, which confirms the importance of these compensating factors for regional ecological systems (Wade \& McVean, 1969; Wardle, 1973).

Latitude determines to a large extent the amplitude of the annual cycle of temperature and, to a lesser extent the amount of precipitation that a region experiences. Mountains tend to amplify some of the characteristics of tropical, mid-latitude and boreal climates for reasons related to topography. Altitude, however, is certainly the most distinguishing and fundamental characteristic of mountain climates, because atmospheric density, pressure and temperature decrease with height in the troposphere. Mountains often sense serve as elevated heat sources, whereby diurnal temperatures are higher than at similar altitudes in the free atmosphere (Flohn, 1968). Diurnal and annual range of temperature tends to decrease with altitude because of the lower heat capacity of the atmosphere at height. The altitudinal controls on mountain climates also exert a significant influence on the distribution of ecosystems. Indeed, there is such a close link between mountain vegetation and climate that vegetation belt typology has been extensively used to define climatic zones and their altitudinal and latitudinal transitions (for example Ozenda, 1985; Quezel \& Barbero, 1990; Klötzli, 1991, 1994; Rameau et al., 1993).

Mountain systems generate their own climates (Ekhart, 1948), as a function of the size of the landmass at a particular elevation. Topographic features also play key role in determining local climates, in particular due to the slope, aspect, and exposure of the surface to climatic elements. These factors tend to govern the redistribution of solar energy as it is intercepted at the surface, as well as precipitation that is highly sensitive to local site characteristics. In many low and mid-latitude regions, precipitation is observed to increase with height; even modest topographic elements can exert an often disproportionate influence on precipitation amount. Precipitation mechanisms are linked to atmospheric dynamics and thermodynamics. When a mass of moist air is forced to rise 
above the condensation level, the excess vapor is converted to fine liquid water particles that become visible in the form of mist, fog or clouds. If uplift of air continues, at some stage precipitation processes will be triggered.

Precipitation in a mountain region will generally fall on the windward-facing slopes of the mountains because of the dynamics associated with uplift. Since most of the moisture is extracted from the clouds on the windward slopes, the air that crosses over to the lee side of the mountains is essentially dry. Death Valley in California, one of the most arid desert regions in the world, is located on the leeward side of the highest part of the Californian Sierra Nevada, which rises to $4417 \mathrm{~m}$ at Mt. Whitney. Indeed, most of the desert regions of the western United States lie to the east of the coastal ranges that are located close to the Pacific coasts of North America. Precipitation gradients are steep from one side of the ranges to the other; for example, San Francisco, California receives an average of $475 \mathrm{~mm}$ of precipitation annually (double or triple that amount in the upper reaches of the Sierra Nevadas), while Las Vegas, Nevada receives only $99 \mathrm{~mm}$. On more local scales, the windward and leeward influences on precipitation are particularly marked on islands which have a significant orography; the main city of Big Island, Hawaii (Hilo) experiences close to $3500 \mathrm{~mm}$ annually, while the resort areas of Kailua-Kona, situated in the lee of the $4000 \mathrm{~m}$ Mauna Laua and Mauna Kea volcanoes, receive a sparse $65 \mathrm{~mm}$ annually.

\section{Particular features of mountain climates}

Solar radiation is intercepted differently according to the orientation of slopes. In the mid- and highlatitudes of the northern hemisphere, slopes oriented towards the south receive more energy per unit area and therefore experience larger thermal amplitude than slopes with different orientations. Differential absorption and distribution of energy at the surface leads to different atmospheric responses, because air in contact with a warm surface tends to rise, as opposed to air in the vicinity of a colder surface. Air at the same elevation in the center of a valley also warms less rapidly than the air in direct contact with the ground, so that the density differences from one side of the valley to another are capable of driving local mountain and valley breezes. Since less dense air moves up the valley slopes, it needs to be replaced by air from lower down in the valley; during the day, therefore, flow close to the valley floor is directed up-valley. The reverse situation occurs at night, when energy at the surface is lost through infrared radiation and cools the air in contact with the surface; continuity principles imply that the air moving downward toward the valley floor needs to be evacuated and as a result, nocturnal flows are directed down-valley.

This cyclic pattern of up- and down-valley air is present in all mountain regions, and each valley can be considered to have its own unique microclimate. Mountain and valley breezes are important in industrialized or urbanized valleys because of their effect on air quality through the recycling and dispersal of pollutants of local origin.

At night, or during periods of persistently stable high pressure conditions, temperature inversions form as a result of high energy loss by infrared terrestrial radiation. Under such circumstances, cold air accumulates at the bottom of a valley floor and tends to stagnate because of the constraining effects of the valley boundaries. The depth of the inversion depends on local weather and topographic characteristics, but in general does not exceed $1000 \mathrm{~m}$. Temperatures above the inversion are milder, because the colder, denser air flows to the valley floor and remains there. It is only at much higher elevations that the general rule of decreasing temperatures with height is verified once again. According to local site characteristics, i.e., valley floor, mountain slope, or mountain top, temperatures at equivalent elevations exhibit large differences in the diurnal and annual range of temperatures. Topographically induced local climates have strong implications for the distribution of climate-sensitive systems, such as vegetation, snow and ice.

\section{Atmospheric pollution in mountain regions}

As in many other cases of environmental stress, exogenous factors contribute to the overall environmental impacts in mountains and uplands. Air pollution is one such stress factor that has a number of ecological consequences, because it is so readily transported by atmospheric circulations from the emission sources to the receptor areas. 
The distances covered by chemical compounds in the atmosphere can cover large distances, according to the type of pollutant, its chemical reactivity and the dominant airflows in which they are embedded. As a result, particulate matter or acidic compounds can be detected in remote mountain regions that are far removed from their source regions.

$\mathrm{NO}_{2}$ is one of the precursor gases of ozone $\left(\mathrm{O}_{3}\right)$, which is a highly corrosive and toxic gas that damages plants and leads to respiratory and ocular problems when found at sufficiently high concentrations. Ground-level ozone is not emitted directly into the atmosphere, but is a secondary pollutant produced by reaction between nitrogen dioxide $\left(\mathrm{NO}_{2}\right)$, hydrocarbons and sunlight. Whereas nitrogen dioxide $\left(\mathrm{NO}_{2}\right)$ participates in the formation of ozone, nitrogen oxide (NO) destroys ozone to form oxygen $\left(\mathrm{O}_{2}\right)$ and nitrogen dioxide $\left(\mathrm{NO}_{2}\right)$. For this reason, ozone levels are not as high in urban zones (where high levels of NO are emitted from vehicles) as in non-urban areas. As the nitrogen oxides and hydrocarbons are transported out of urban regions, the ozone-destroying $\mathrm{NO}$ is oxidized to $\mathrm{NO}_{2}$, which participates in ozone formation. Ozone can therefore be present in mountain areas located at considerable distances from the source regions of the ozone precursors. Ozone is possibly one of the factors responsible for forest dieback in the European Alps for example, where damage to trees is believed to be linked to heavy industrial sites at the boundaries of the mountains, as in northern Italy. As always with environmental threats, the large time lag between load and full reaction, where ecosystems and soils are involved, has probably still not reached the peak impact.

Grassl (1994) has shown that there has been an upward trend in tropospheric ozone concentrations at Alpine sites, such as the Zugspitze, at $2950 \mathrm{~m}$ altitude in Germany, since measurements began in the late 1960s. In contrast, ozone at the nearby urban site of Garmisch-Partenkirchen have not risen (Schneider, 1992), typically because of the ozone-destroying chemical reactions taking place in an urban environment with a high density of motorized traffic. Since sunlight is a prerequisite for the physico-chemical transformation of NO and $\mathrm{NO}_{2}$ into $\mathrm{O}_{3}$, high levels of ozone are generally observed during periods of persistently warm weather, and in locations where poor ventilation allows concentrations of hydrocarbons and nitrogen oxides to reach critical levels. Due to the time required for chemical processing, ozone formation tends to take place downwind of pollution centers. The resulting ozone pollution or "summertime smog" may persist for several days and be transported over long distances.

Sulfur contained in coal, which is used in many industrial processes worldwide (energy supply, smelting, etc.) is released into the atmosphere in the form of sulfur dioxide $\left(\mathrm{SO}_{2}\right)$. This can then be dissolved in liquid water droplets in clouds and fog to form sulfuric acid $\left(\mathrm{H}_{2} \mathrm{SO}_{4}\right)$, which is then transported in atmospheric flows and ultimately falls to the surface in a process known as acid deposition or acid rain, with a number of adverse environmental consequences. Acidification of soils damages vegetation and releases heavy metals such as aluminium, copper or mercury into hydrological systems; these toxic metals are absorbed by fish and other aquatic species, with potentially serious consequences for the food chain. The interactions between living organisms and the chemistry of their aquatic habitats are extremely complex. If the number of one species or group of species changes in response to acidification, then the ecosystem of the entire water body is likely to be affected through predator-prey relationships. Terrestrial animals dependent on aquatic ecosystems for their food supply, such as birds, are also affected.

In the European Alps, the consequences of acid precipitation may be exacerbated in many mountain regions by the fact that precipitation increases with altitude. Smidt (1991) has shown that for two Austrian alpine sites contamination of precipitation with ions resulting from pollution decreases with altitude, but deposition increases because of enhanced precipitation with height. The deposition of hydrogen ions thus strongly increases with height. Since the concentration of basic anions and cations in precipitation is rather uniform over central Europe, the Alps are subject to as much acid deposition as other areas because of the orographic controls on precipitation, despite the fact the Alps are not in themselves a major source of sulfate-based pollutants.

Stratospheric ozone depletion caused by the catalytic destruction of ozone molecules can indirectly affect mountain regions too. This is because the resulting rise in UV-B radiation levels affect 
photochemistry in the troposphere as well as photosynthesis in high altitude mountain areas.

Future trends in pollution and its long-distance transport are difficult to assess. On one hand, increasing industrialization has the potential of generating high levels of pollution. On the other hand, the awareness that pollution is detrimental to human health and the environment has led to policies aimed at controlling emissions, particularly in western Europe, and thus the additional impacts on the Alps may be limited in comparison to other mountain regions of the world where pollution abatement measures are not as readily implemented.

\section{Climate and climatic change in the Alps}

This section will investigate aspects of climate during the 20th century that are specific to the European Alps, and will provide an insight into the manner in which climate may change in the latter part of the 21st century in response to global warming. The European Alps are by far the bestknown mountain area of the world in terms of weather and climate and related environmental characteristics (Barry, 1994). Several summit observatories have records spanning 100 years and there is a dense network of regular observing stations and precipitation gauges. Detailed climatic atlases exist for the Tyrol (Fliri, 1975) and the Swiss Alps (Kirchofer, 2001). The most intensive permanent observation sites, including high elevation stations, are to be found in Switzerland and Austria. The wealth of data that is available for the alpine domain makes this a privileged region for climatic and environmental studies. In Switzerland, homogenous daily data is available in digital form from 1901 at many locations (Bantle, 1989; Begert et al., 2003).

The geographical location and configuration of the Alps makes it a particularly interesting region for many climate and environmental studies, because the mountains are at a "climatic crossroads" that include oceanic, continental, polar, Mediterranean and, on occasion, Saharan influences. The Alps consist of an arc that stretches first in a north-south direction from the Mediterranean in France that then curves eastwards through Switzerland and finally stretches in an east-west direction as far as eastern Austria. The Alps are to some extent bounded by the competing influences of the Mediterranean, the Atlantic, and to a lesser extent the North Sea and the Baltic, and are located in one of the warmest areas of the Northern Hemisphere mid-latitudes as a result of the proximity of the modulating influence of the Atlantic Ocean and the heat reservoir that the Mediterranean Sea represents. The alpine arc is subject to the influence of storms that cross the Atlantic or develop in the Mediterranean, but can also influence weather patterns in several ways, for example through lee cyclogenesis (the development of low-pressure systems resulting from the interaction between large-scale atmospheric flows and topography), contributing to the formation and persistence of blocking high pressure systems, and in the triggering of turbulent mountain waves (gravity waves) whose influence can be felt far downstream of the mountains themselves.

The Alps simultaneously exhibit characteristics related to continentality and to latitude, as seen in Figure 1. Here, monthly-means of temperature (Fig. 1a) and precipitation (Fig. 1b) have been plotted for the climatological reference period 1961-1990 at Lugano (located at $290 \mathrm{~m}$ above sealevel to the south of the Alps), Zurich (567 m above sea-level, to the north of the Alps), and Säntis, in the northeastern Swiss Alps at $2500 \mathrm{~m}$ above sea level. The three temperature curves are in phase but shifted as a result of the altitude difference and the generally warmer Mediterranean influences in the case of Lugano. The precipitation statistics exhibit a wide discrepancy between sites; Lugano has a double peak of precipitation in spring and late summer, associated with convective precipitation, while in Zürich precipitation peaks in the summer and is at a minimum during the coldest months of the year (continentality effects). Precipitation is highest at Säntis due to the effect of orographically induced rain and snow, and exhibits a much-reduced amount of precipitation in the autumn.

Figure 2 shows the changes in yearly surface temperature anomalies during the 20th century at the same three locations as in Figure 1, as a representative example of changes that have occurred in the alpine region at various altitudes and latitudes. The anomalies are computed as the difference between daily mean temperatures and the 

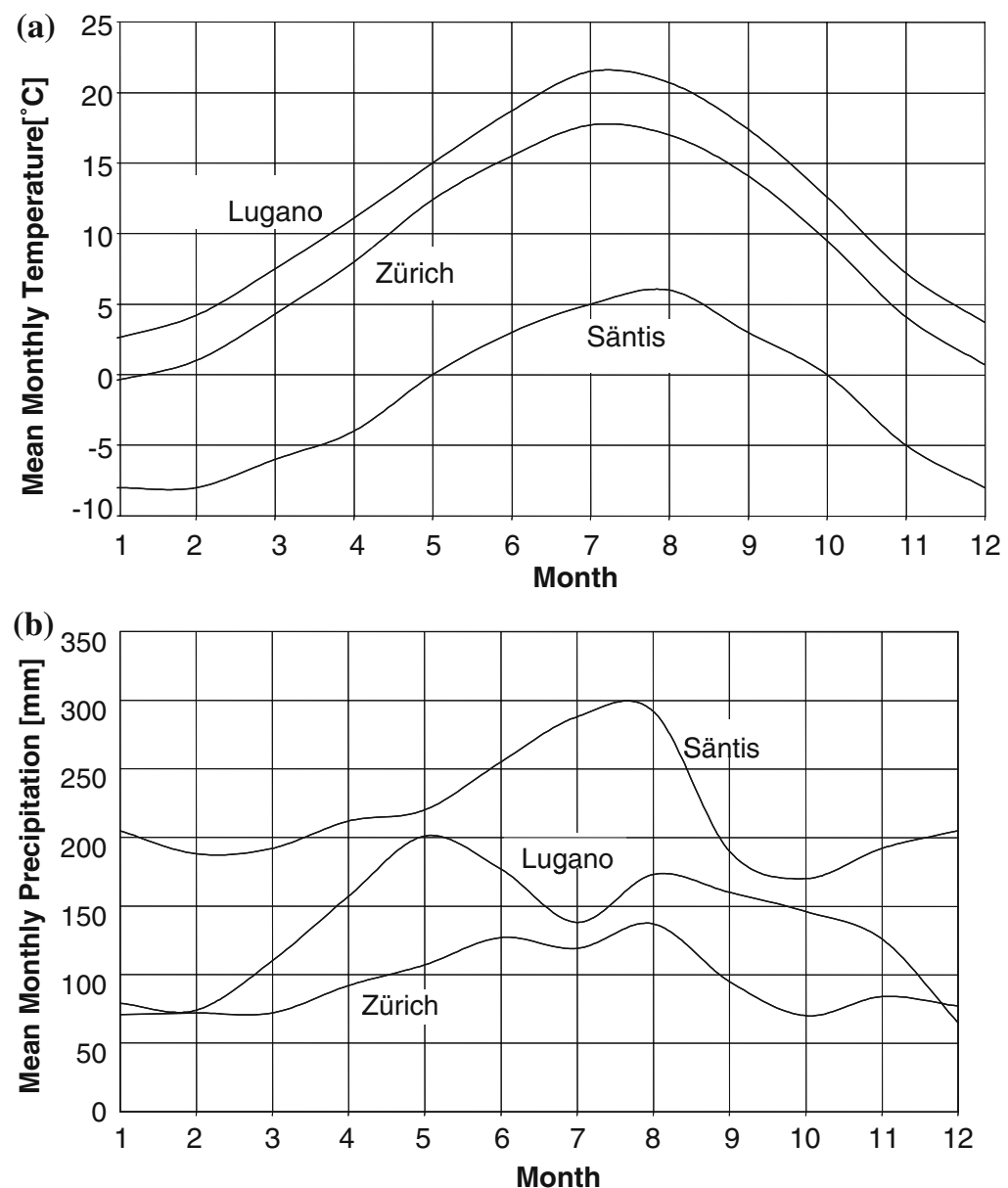

Figure 1. Monthly temperature (a) and precipitation (b) statistics, averaged over the 1961-1990 climatological reference period for Lugano, Zürich, and Säntis.

mean daily average for the 1961-1990 period, and then averaged to provide the annual value that is represented here. In order to remove the noisiness of year-to-year variability, the data has been smoothed with a five-point filter for the purposes of clarity. All three curves are in phase, and the anomalies are essentially identical from the middle of the 20th century. The global data described in Jones and Moberg (2003) has been superimposed on this graph to illustrate the fact that the temperature change in the Alps is more marked than on a global or hemispheric scale; the warming experienced since the early 1980 s, while synchronous with warming at the global scale, is however of far greater amplitude and exceeds $1.5^{\circ} \mathrm{C}$ for the Säntis data, which represents roughly a three-fold amplification of the global climate signal (Diaz \& Bradley, 1997).

Beniston (2000) has summarized the trends in other climatic variables. He concludes that climate change in the alpine region has been characterized during the 20th century by increases in minimum temperatures of over $2{ }^{\circ} \mathrm{C}$ in some locations, a more modest increase in maximum temperatures with the exception of the sudden jump in maxima resulting from the 2003 heat wave that affected much of western and central Europe, and little trend in the average precipitation data. Several periods of warming are observed during the instrumental record, with the 1940s exhibiting a particularly strong warming and then a cooling into the 1950s, probably associated with increased 


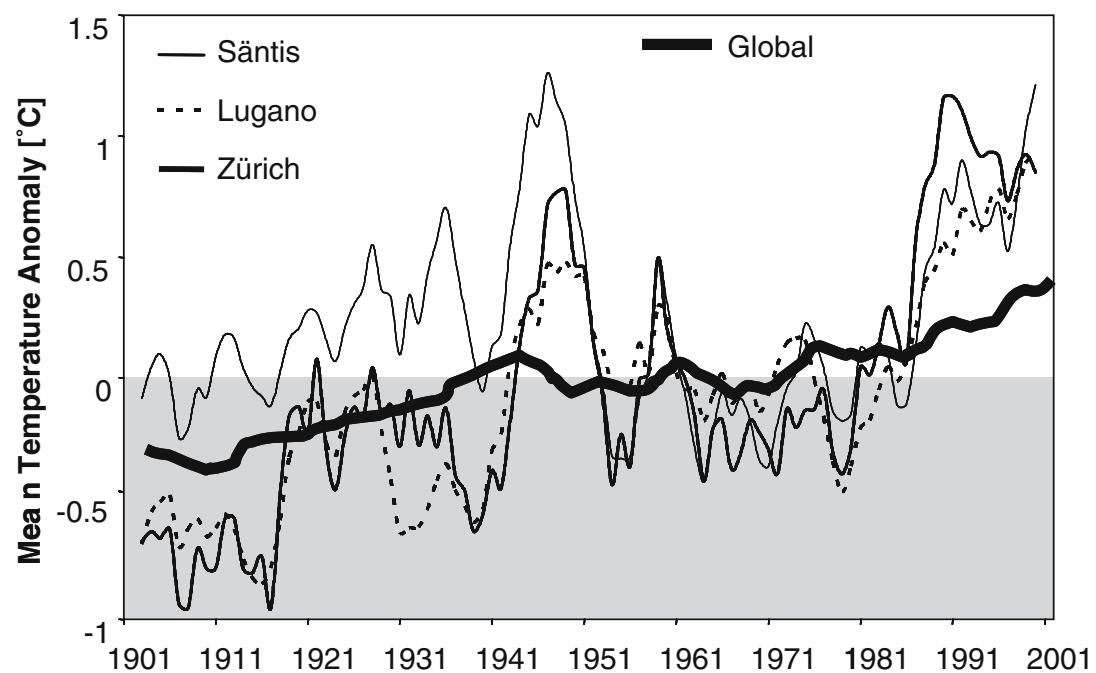

Figure 2. Temperature departures from the 1961-1990 climatological mean in the Swiss Alps compared to global temperature anomalies.

solar energy fluxes (Friis-Christensen \& Lassen, 1991).

The most intense warming occurs in the 1990s, however (Jungo \& Beniston, 2001), a behavior that can be explained in part by the influence of the North Atlantic Oscillation (Beniston \& Jungo, 2002). During the last decade of the 20th century, persistently positive values of the North Atlantic Oscillation (NAO) index were observed. The NAO index is based on the pressure difference between the Azores and Iceland and is an indirect measure of the intensity of the atmospheric general circulation over the North Atlantic; its behavior can account for over $60 \%$ of the variability of climate in both the eastern third of North America and a major part of western and central Europe (Hurrell, 1995). When the NAO index is high, alpine climate tends to respond through lower-than-average precipitation and higher-than-average temperatures. The bias imposed by the highly positive NAO index on temperatures has been shown to exceed $1{ }^{\circ} \mathrm{C}$ for minimum temperatures, according to Beniston and Jungo (2002). The shape of the probability density function (PDF) of temperature also changes when the NAO index shifts from low to high values. In the example given in Figure 3 for the Säntis measurement site of eastern Switzerland, the frequency of temperatures exceeding the freezing point during the winter season is more than doubled during periods of high NAO index compared to periods with low index values, thus enhancing the potential for early snowmelt, for example.

The importance of snow in terms of environmental (e.g. hydrology, vegetation) and economic systems (e.g. tourism, water management) has been stressed in numerous studies (inter alia, Haeberli \& Beniston, 1998; Beniston, 2000). A quantification of the amount of snow in the mountains and the changes that occur with shifts in climate is crucial for assessing the amount of water that will ultimately runoff and be routed into the numerous river systems originating in the Alps in the spring and early summer. The Alps in general, and Switzerland in particular, have in the past been referred to as "the water tower of Europe" (Mountain Agenda, 1998). Any substantial changes in the mountain snow pack would have a significant impact on the flow of many major river basins, not only because of changes in the amount and timing of runoff, but also because of the potential for enhanced flooding, erosion, and associated natural hazards. The timing of snow melt is also a major determinant for initiating the vegetation cycle of many alpine plant species, and hence its quantification is necessary when assessing the response of vegetation to climatic change (Prock \& Körner, 1996; Myneni et al., 1997; Keller \& Körner, 2003). 


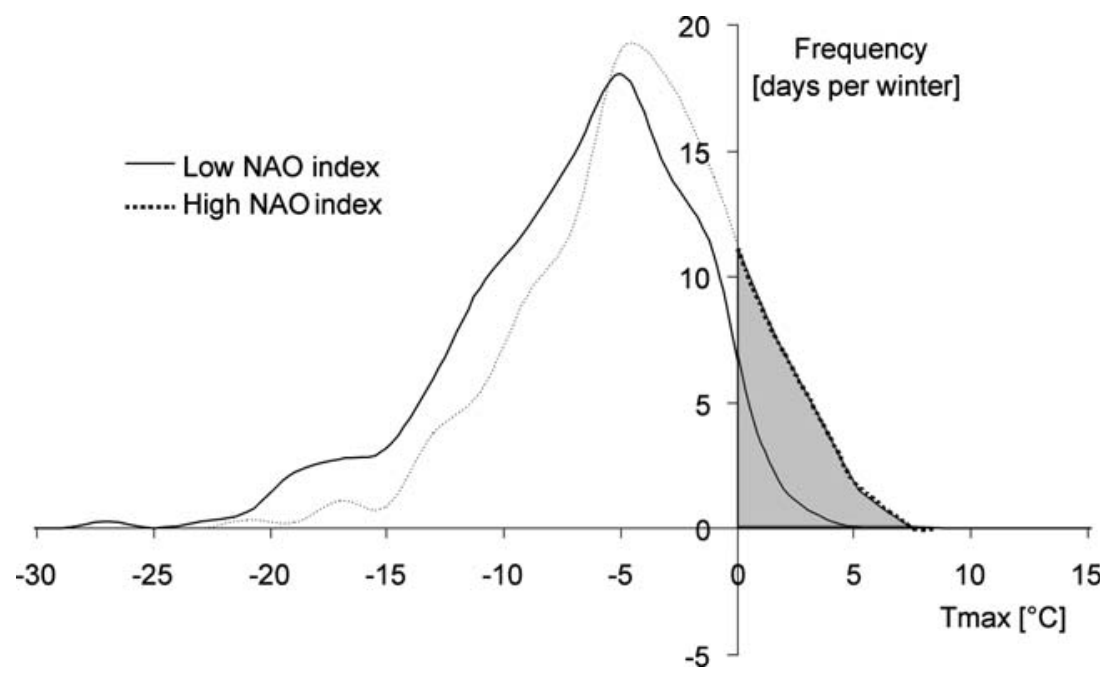

Figure 3. Response of mean winter-season maximum temperature distribution at the high elevation site of Säntis (2500 m above sealevel, in the northeastern Swiss Alps) to opposing behavior of the North Atlantic Oscillation index.

Figure 4 illustrates the manner in which the alpine snow-pack has responded in the past decades to the degree of climatic change experienced in the Alps (Beniston et al., 2003). The data for each of the selected sites shows that while there is a strong interannual variability, overall the trends in snow amount have not changed substantially; this is because the rate of warming that has occurred in the course of the 20th century is still relatively modest compared to what is projected to take place in the future, so that snow still falls during the winter months at most locations. At elevations below about $1200 \mathrm{~m}$, there has been a reduction in the total amount of snow and also in the duration of the snow season since the mid-1980s, but this remains well within the bounds of annual variability despite the strong warming that has intervened particularly in winter since about 1985. Säntis, like other sites above $2000 \mathrm{~m}$, has experienced an increase in the amount of snow; this could indeed be related to warmer temperatures and certainly more precipitation in the last two decades that has fallen in the form of snow at high elevations (thus accumulating more snow over a longer season) and rain at low elevations (thus reducing the potential for snow accumulation).

Glacier mass balance, on the other hand, has responded very sensitively and negatively to warming since the termination of the "Little Ice Age" in Europe in the mid-nineteenth century (Haeberli \& Beniston, 1998). The principal explanation is related to the fact that most alpine glaciers have a surface temperature close to the freezing point, so that any minor increase in temperature in the mountains can have a major and negative impact on the glaciers (Haeberli, 1995). Since 1850, Haeberli (1990) estimates that $40 \%$ of the surface area of glaciers in the Alps and over $50 \%$ of their volume have disappeared as a result of climatic change.

The complexity and mutual inter-dependency of mountain environmental and socio-economic systems pose significant problems for climate impacts studies (Beniston et al., 1997), essentially because the current spatial resolution of General Circulation Climate Models (GCM) still remains too crude to adequately represent the topographic detail of most mountain regions. Most impacts research requires information with fine spatial definition, where the regional detail of topography and land-cover are important determinants in the response of natural and managed systems to change. Since the mid-1990s, the scaling problem related to complex topography has been addressed through regional modeling techniques, pioneered by Giorgi and Mearns (1991, 1999), and through statistical-dynamical downscaling techniques (e.g. Zorita \& von Storch, 1999).

So-called "nested" approaches to regional climate simulations, whereby large-scale data or GCM outputs are used as boundary and initial conditions for regional climate model (RCM) simulations, have been applied to scenario computations 


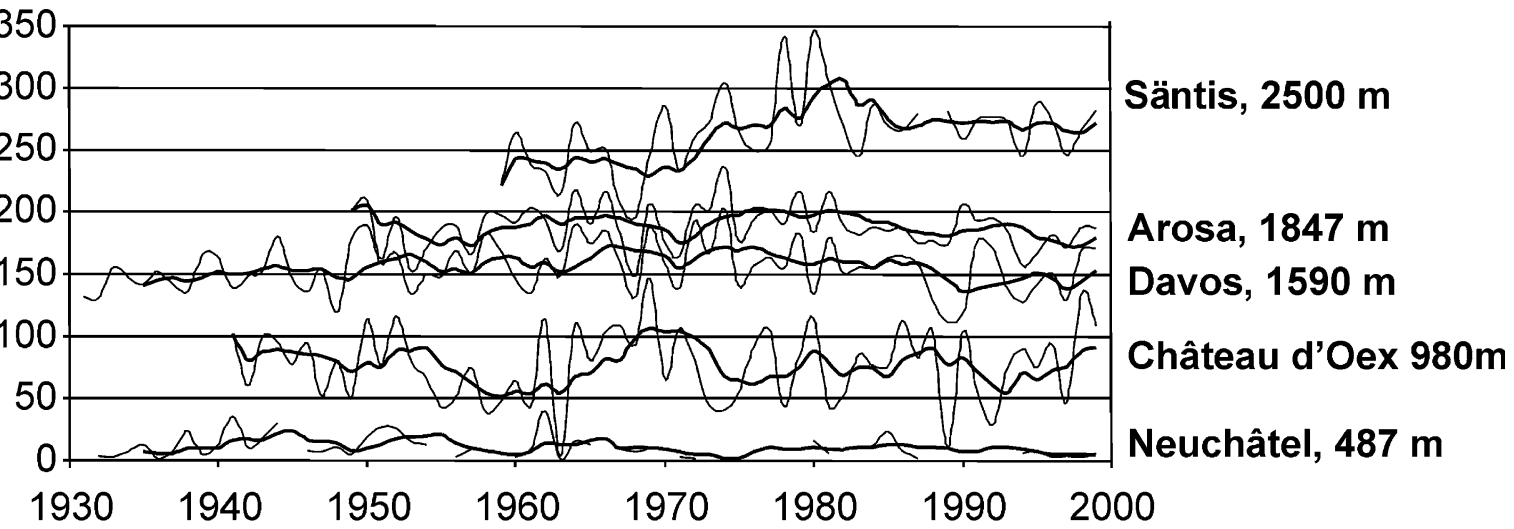

Figure 4. Time-series of maximum seasonal snow depth at a number of Swiss observation sites in the course of the 20th century.

for climatic change in the 21st century (Giorgi \& Mearns, 1999). The technique is applied to specific periods in time ("time windows") for which highresolution simulations are undertaken over a given geographical area. The nested modeling approach represents a trade-off between decadal- or centuryscale, high resolution simulations that are too computationally expensive to attempt, and relying only on coarse resolution results provided by longterm GCM integrations. Although the method has a number of drawbacks, in particular the fact that the nesting is "one-way" (i.e. the climatic forcing occurs only from the larger to the finer scales and not vice versa), RCMs have shown their capacity in generally improving the regional detail of climate processes. This is an advantage in areas of complex topography, in particular where orographically enhanced precipitation often represents a significant fraction of annual or seasonal rainfall.

Over time, the increase in spatial resolution of RCMs has allowed an improvement in the understanding of regional climate processes and the assessment of the future evolution of regional weather patterns influenced by a changing global climate. Marinucci et al. (1995) tested the nested GCM-RCM technique at a $20-\mathrm{km}$ resolution to assess its adequacy in reproducing the salient features of contemporary climate in the European Alps, while Rotach et al. (1997) repeated the numerical experiments for a scenario of enhanced greenhouse-gas forcing. Since the mid-1990s, RCM spatial resolution has continually increased, partially as a response to the needs of the impacts community. Currently, detailed simulations with
$5 \mathrm{~km}$ or even $1 \mathrm{~km}$ grids are used to investigate the details of precipitation in relation to surface runoff, infiltration, and evaporation (e.g. Arnell, 1999; Bergström et al., 2001), extreme events such as precipitation (Frei et al., 1998), and damaging windstorms (Goyette et al., 2001). This is an interesting development for impacts studies, because extreme climatological events tend to have a greater impact on natural and socio-economic systems than changes in mean climate.

When applied to climate change scenarios, global and regional models are powerful tools that allow an insight into the possible climate futures in response to various levels of greenhouse gas emissions and concentrations (IPCC, 2001). According to the scenario, the response of climate ranges from an increase in global mean temperatures of 1.5-5.8 ${ }^{\circ} \mathrm{C}$. These scenarios (Nakicenovic et al., 2000) are based on the emissions of greenhousegases in the atmosphere that will depend on pathways of economic and population growth, hypotheses related to technological advances, the rapidity with which the energy sector may reduce its dependency on fossil fuels, and other socio-economic projections related to deforestation and landuse changes.

Within the European Union project PRUDENCE (EVK2-CT-2100-00132), a suite of regional climate models have been applied to the investigation of climatic change over Europe for the last 30 years of the 21 st century, enabling changes in a number of key climate variables to be assessed (Christensen et al., 2002). When comparing model results for future temperature change influenced by 
enhanced greenhouse-gas concentrations, there is a generally close agreement between many of the models. The HIRHAM4 regional climate model (RCM) of the Danish Meteorological Institute (Christensen et al., 1998) has thus been selected as one of the representative models for investigating future trends in summer maxima; this model operates at a $50-\mathrm{km}$ resolution and has completed two 30 -year simulations, i.e. "current climate" or the "control simulation" for the period 1961-1990, and the future "greenhouse-gas climate" for the period 2071-2100. Of the range of possible emission scenarios, only results based on the IPCC SRES A2 scenario (Nakicenovic et al., 2000) are discussed here; A2 assumes a high level of emissions in the course of the 21 st century, resulting from low priorities on greenhouse-gas abatement strategies and high population growth in the developing world. The A2 scenario leads to atmospheric $\mathrm{CO}_{2}$ levels of about 800 ppmv by 2100 (three times their preindustrial values) and provides an estimate of the upper bound of climate futures discussed by the IPCC (2001). The fully-coupled ocean-atmosphere general circulation model (GCM) of the UK Hadley Centre, HADCM3 (Johns et al., 2003) has been used to drive the higher-resolution atmospheric HadAM3H model (Pope et al., 2000), that in turn provides the initial and boundary conditions for the RCMs used in the PRUDENCE project, including HIRHAM4.

Although the RCM grid is a relatively coarse $50 \mathrm{~km}$, the results confirm earlier studies by Marinucci et al. (1995) and Rotach et al. (1996) that tend to show that alpine climate in the latter part of the $21 \mathrm{st}$ century will be characterized by warmer and more humid winter conditions, and much warmer and drier conditions in the summer. Winter minimum temperature increases at the lower elevations of Switzerland, for example, such as Basel, Geneva, or Zurich, are projected to be in the range of $4^{\circ} \mathrm{C}$, while summer temperatures will exceed $5.5-6{ }^{\circ} \mathrm{C}$ compared to current values based on the 1961-1990 climatological mean record. Precipitation change in the Swiss Alps exhibits a more heterogeneous behavior than temperature, with winter precipitation decreasing marginally $(2-3 \%)$ in some lowelevation sites and increasing at higher elevations, while summer precipitation is projected to decrease by $15-20 \%$ in most parts of the alpine chain. According to Christensen \& Christensen (2003),
Schär et al. (2004) and others, reductions in average summer precipitation may be simultaneously accompanied by a sharp increase in short but potentially-devastating heavy precipitation events in many parts of Europe, including the Alps. The sharp reduction in mean precipitation in summer explains the much stronger warming that occurs in the Alps and other parts of Europe than in winter: cloudiness is reduced and therefore more incoming solar energy is available to warm the surface; in addition, soil moisture diminishes, thereby imposing a positive feedback on the lower atmosphere. Slightly enhanced winter precipitation, on the other hand, implies a small increase in snow accumulation but at higher altitudes than today, but more rainfall at or below 1500-2000 m above sea level (Beniston et al., 2003). It is not expected that the increase in winter accumulate compensate to any large extent the direct influence of more elevated temperatures on glacier mass balance, however. Glaciers are likely to lose between 50 and $90 \%$ of their remaining mass, according to the extent of warming, by the end of the 21st century (Haeberli \& Beniston, 1998).

Impacts of climatic change on physical systems will affect water, snow and ice, and shifts in extremes will lead to changes in the frequency and intensity of natural hazards. Water availability in some regions may decline because of a reduction in precipitation amounts, and also because of the reduced snow-pack and snow season in many mountain regions. Changes in snow amount will lead to significant changes in the timing and amount of runoff in various hydrological basins. Water supply to more populated areas outside the mountains themselves will be influenced by shifts in precipitation regimes (both rain and snow) in the source regions of many of Europe's rivers (Beniston et al., 1996).

A key variable that controls the various components of the hydrological cycle contributing to discharge in alpine rivers is the behavior of the winter snow-pack, that determines the timing and amount of runoff that will feed into rivers during the snow-melt season. A two-dimensional representation in temperature-precipitation space presented by Beniston et al. (2003) shows that as a result of the expected winter minimum temperature warming of more than $4{ }^{\circ} \mathrm{C}$ by the end of the 21 st century, a reduction in snow duration by more than 100 days is likely to occur at the Säntis 
and at Arosa sites that have been represented in Figures 5 and 6 (Beniston et al., 2004). The increase in winter precipitation that intervenes during this period only slightly modulates the dominant effect of the $+4{ }^{\circ} \mathrm{C}$ warming. The "migration" of the Arosa and Säntis statistics can be considered to be highly significant, because the location of snow duration in the temperatureprecipitation space by the 2070s is well outside the range of natural variability of current snow duration. This variability is defined by the ellipses that are centered on the average temperature-precipitation data for the two alpine sites (see Beniston et al., 2003, for more details).

In a changed climate, meteorological extremes may also occur in regions that are today less prone to such events, and vice versa. Due to the amount of precipitation and relief, the added effect of intense rainfall in low to middle altitude regions is to produce some of the highest global rates of slope erosion. Climate change could alter the magnitude and/or frequency of a wide range of geomorphologic processes (Dehn et al., 2000).
Increases in extreme precipitation events, associated with snowmelt, could increase the frequency and severity of floods (Govi, 1990). Such extreme events would affect erosion, discharge and sedimentation rates, which damage hydropower infrastructure; furthermore, sediments deposited in large quantities on agricultural lands, irrigation canals and streams would lead to reductions in agricultural production (Garr \& Fitzharris, 1994).

Due to a much longer growing season and higher temperatures, the European alpine areas will in the 21 st century face a considerable upward shift in the alpine tree lines of 300-400 m (Holten, 1990; Holten \& Carey, 1992). Depending on the magnitude of temperature increase, the response time for the invasion of mountain birch into the current low alpine zone, can be fairly short, and easily be observed within 2-3 decades (Woodward et al., 1995). The areal reductions of the alpine zones will probably be relatively smaller in the Alps, due to the higher and very often steeper mountains. Melting of permafrost and changes in
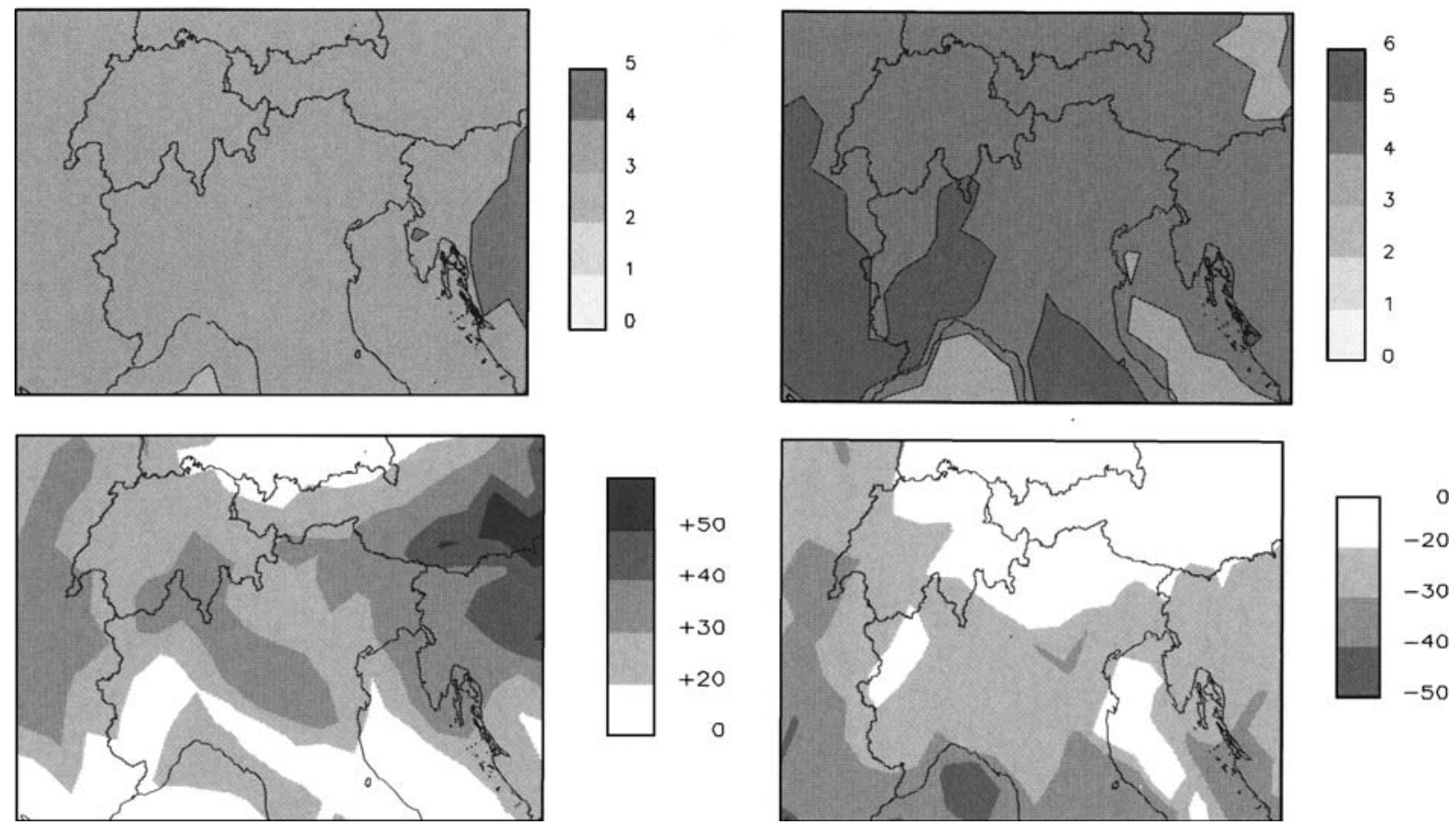

Figure 5. Regional Climate Model simulations of the possible response of climate in the Alpine region to increased greenhouse gas concentrations for the IPCC A2 scenario (Nakicenovic et al., 2000). Upper left: Change in winter-mean temperatures $\left({ }^{\circ} \mathrm{C}\right)$; upper right: Change in summer-mean temperatures $\left({ }^{\circ} \mathrm{C}\right)$; lower left: Change in winter-mean precipitation $(\%)$; lower right: Change in summer-mean precipitation (\%). Figures courtesy of B. Koffi, University of Fribourg. 


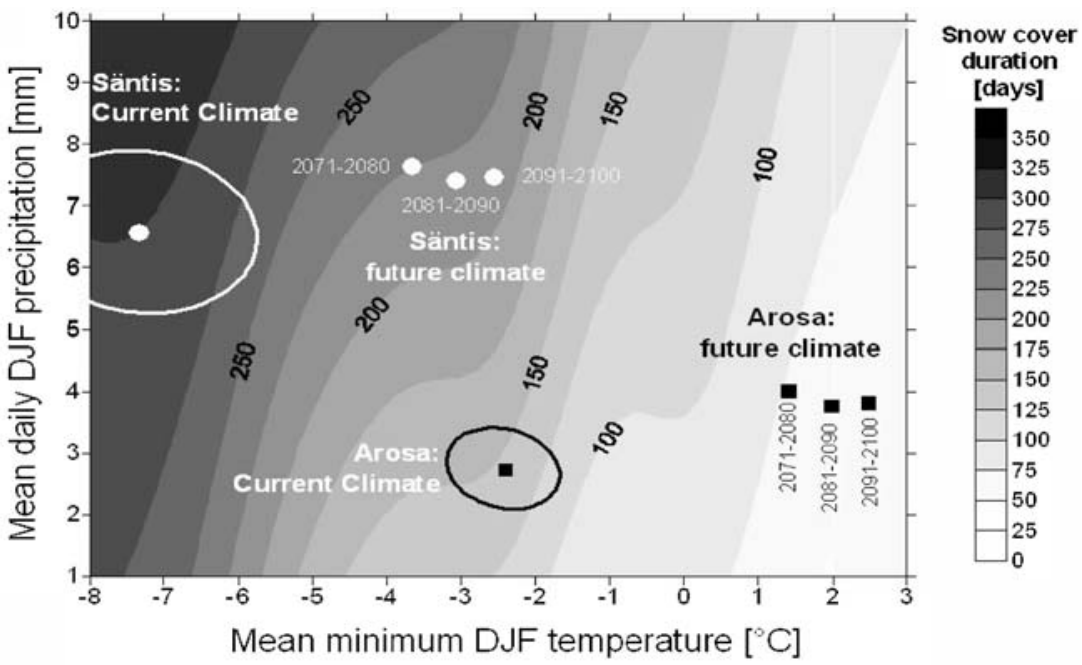

Figure 6. 2-D contour surfaces of snow-cover duration as a function of winter (DJF) minimum temperature and precipitation, based on the data extracted from all climatological sites used in this study. Superimposed on this figure is the temperature-precipitation-snow duration data for the Arosa and Säntis sites, for current climatic conditions, and for the three last decades of the 21 st century (see text for details). The ellipses show the $2 \sigma$ range of DJF minimum temperature and precipitation, and corresponding spread of snow-cover duration for Arosa, and Säntis. The orientation of the ellipses is related to the covariance of temperature and precipitation. The figures on the isolines identify the length of the snow season.

hydrology at higher altitudinal levels will change the ecological conditions in steep mountain slopes, making them much more unstable, probably causing a higher frequency and maybe intensity of avalanches and landslides.

\section{Conclusions}

There is a large consensus as to the very real threat which abrupt global warming poses to a wide range of environmental, social and economic systems both globally and regionally such as in the Alps. The IPCC $(1996,1998,2001)$ has been instrumental in providing the state-of-the-art information on climatic change and its environmental and economic consequences, so that while science can continue to refine its predictions for the future, there is sufficient material to justify joint international action for reducing the risks related to climatic change and to define strategies for adapting to change as soon as possible, before such actions become much more costly in the future.

The United Nations Framework Convention on Climate Change (FCCC) has the explicit objective of protecting the climate system, through political, economic and legal measures destined to reduce the emissions of greenhouse gases in the atmosphere and ultimately to stabilize their concentrations. Indeed, in terms of ecological systems, Article 2 of the FCCC explicitely states that:

"...The ultimate objective of the FCCC... is the stabilization of greenhouse gas concentrations at a level which would prevent dangerous anthropogenic interference with the climate system. Such a level should be achieved within a timeframe sufficient to allow ecosystems to adapt naturally to climate change, to ensure that food production is not threatened and to enable economic development to proceed in a sustainable manner..."

In facing up to environmental change, it will be necessary to think in terms of decades and centuries, because the impacts of these profound changes may not become unambiguously apparent for several generations. Many of the policies and decisions related to pollution abatement, climatic change, deforestation or desertification would provide opportunities and challenges for the private and public sectors. A carefully selected portfolio of national and international responses 
aimed at mitigation, adaptation and improvement of knowledge can reduce the risks posed by environmental change to ecosystems, food security, water resources, human health and other natural and socio-economic systems.

\section{References}

Arnell, N., 1999. The effect of climate change on hydrological regimes in Europe. Global Environmental Change 9: 5-23.

Bantle, H., 1989. Program Documentation for the Swiss Climate Database at the Computing Center of ETH-Zurich. MeteoSuisse publication, Zürich, Switzerland:.

Barry, R. G., 1994. Past and potential future changes in mountain environments: a review. In Beniston, M. (ed.), Mountain Environments in Changing Climates. Routledge Publishing Company, London and New York, 3-33.

Becker, A. \& H. Bugmann (eds), 1997. Predicting Global Change Impacts on Mountain Hydrology and Ecology: Integrated Catchment Hydrology/Altitudinal Gradient Studies. International Geosphere-Biosphere Programme (IGBP) Report 43, Stockholm.

Begert, M., et al. 2003. Homogenization of climate time series and computation of the 1961-1990 norms. MeteoSuisse Publication, Zürich, Switzerland (in German), 67, 170 pp.

Beniston, M., 2000. Environmental Change in Mountains and Uplands. Arnold/Hodder and Stoughton/Chapman and Hall Publishers, London, UK, and Oxford University Press, New York, USA, 172 pp.

Beniston, M., 2003. Climatic change in mountain regions: a review of possible impacts. Climatic Change 59: 5-31.

Beniston, M., H. F. Diaz \& R. S. Bradley, 1997. Climatic change at high elevation sites; a review. Climatic Change 36: 233-251.

Beniston, M., D. G. Fox, S. Adhikary, R. Andressen, A. Guisan, J. Holten, J. Innes, J. Maitima, M. Price \& L. Tessier, 1996. The Impacts of Climate Change on Mountain Regions. Second Assessment Report of the Intergovernmental Panel on Climate Change (IPCC), Chapter 5, Cambridge University Press, 191-213.

Beniston, M. \& P. Jungo, 2002. Shifts in the distributions of pressure, temperature and moisture in the alpine region in response to the behavior of the North Atlantic Oscillation. Theoretical and Applied Climatology 71: 29-42.

Beniston, M., F. Keller \& S. Goyette, 2003. Snow pack in the Swiss Alps under changing climatic conditions: an empirical approach for climate impacts studies. Theoretical and Applied Climatology 74: 19-31.

Beniston, M., F. Keller, B. Koffi \& S. Goyette, 2004. Estimates of snow accumulation and volume in the Swiss Alps under changing climatic conditions. Theoretical and Applied Climatology 76: 125-140.

Bergström, S., B. Carlsson, M. Gardelin, G. Lindström, A. Pettersson \& M. Rummukainen, 2001. Climate change impacts on runoff in Sweden - assessments by global climate models, dynamical downscaling and hydrological modelling. Climate Research 16: 101-112.
Christensen, J. H. \& O. B. Christensen, 2003. Severe summertime flooding in Europe. Nature 421: 805-806.

Christensen, J. H., T. R. Carter \& F. Giorgi, 2002. PRUDENCE employs new methods to assess European climate change. EOS, Transactions of the American Geophysical Union 83: 147 .

Christensen, O. B., J. H. Christensen, B. Machenhauer \& M. Botzet, 1998. Very high-resolution regional climate simulations over Scandinavia - Present climate. Journal of Climate 11: 3204-3229.

Dehn, M., G. Bürger, J. Buma \& P. Gasparetto, 2000. Impacts of climate change on slope stability using expanded downscaling. Engineering Geology 55: 193-204.

Diaz, H. F. \& R. S. Bradley, 1997. Temperature variations during the last century at high elevation sites. Climatic Change 36: 253-279.

Ekhart, E., 1948. De la structure de l'atmosphère dans la montagne. La Météorologie 3: 3-26.

Fliri, F., 1975. Das Klima der Alpen im Raume von Tirol. Universitäts Verlag Wagner, Innsbruck, München.

Flohn, H., 1968. Contributions to a meteorology of the Tibetan Highlands. Atmospheric Physics Paper 130, Dept. of Atmospheric Sciences, Colorado State University, Fort Collins, $120 \mathrm{pp}$.

Frei, C., C. Schär, D. Lüthi \& H. C. Davies, 1998. Heavy precipitation processes in a warmer climate. Geophysical Research Letters 25: 1431-1434.

Friis-Christensen, E. \& K. Lassen, 1991. Length of the solar cycle, an indication of solar activity closely associated with climate. Science 254: 698-700.

Garr, C. E. \& B. B. Fitzharris, 1994. Sensitivity of mountain runoff and hydro-electricity to changing climate, Mountain Environments in Changing Climates, M. Beniston, (ed.), Routledge Publishing Company, London and New York, 366-381.

Giorgi, F. \& L.O. Mearns, 1991. Approaches to the simulation of regional climate change: a review. Reviews of Geophysics 29: 191-216.

Giorgi, F. \& L.O. Mearns, 1999. Regional climate modeling revisited. Journal of Geophysical Research 104: 63356352 .

Govi, M., 1990. Conférence spéciale: Mouvements de masse récents et anciens dans les Alpes italiennes. Proceedings of the Fifth Symposium on Landslides, Lausanne, 3, 1509-1514.

Goyette, S., M. Beniston, P. Jungo, D. Caya \& R. Laprise, 2001. Numerical investigation of an extreme storm with the Canadian Regional Climate Model: The case study of windstorm Vivian, Switzerland, February 27, 1990. Climate Dynamics 18: 145-168.

Grassl, H., 1994. The Alps under local, regional and global pressures. In Beniston, M. (ed.), Mountain Environments in Changing Climates. Routledge Publishing Company, London and New York, 34-41.

Haeberli, W., 1990. Glacier and permafrost signals of 20th century warming. Annals of Glaciology 14: 99-101.

Haeberli, W., 1995. Glacier fluctuations and climate change detection - operational elements of a worldwide monitoring strategy. World Meteorological Organization (WMO) Bulletin $44,1,23-31$. 
Haeberli, W. \& M. Beniston, 1998. Climate change and its impacts on glaciers and permafrost in the Alps. Ambio 27: 258-265.

Hedberg, O., 1964. The phytogeographical position of the afroalpine flora, Recent Advances in Botany, 914-919.

Holten, J. I. \& P. D. Carey, 1992. Responses of climate change on natural terrestrial ecosystems in Norway. NINA Institute Research Report 29: 1-59.

Holten, J. I. (ed.), 1990. Biological and ecological consequences of changes in climate in Norway. NINA Institute Research Report 11: 1-59.

Hurrell, J. W., 1995. Decadal trends in the North Atlantic Oscillation regional temperatures and precipitation. Science 269: 676-679.

IPCC, 1996. Climate Change. The Intergovernmental Panel on Climate Change (IPCC) Second Assessment Report. Cambridge University Press, Cambridge and New York. Volumes I (Science), II (Impacts) and III (Socio-economic implications).

IPCC, 1998. The Regional Impacts of Climate Change. Cambridge University Press, Cambridge and New York, 517.

IPCC, 2001. Climate Change. The Intergovernmental Panel on Climate Change (IPCC) Third Assessment Report. Cambridge University Press, Cambridge and New York.

Johns, T. C, 2003. Anthropogenic climate change for 1860 to 2100 simulated with the HadCM3 model under updated emission scenarios. Climate Dynamics 20: 583-612.

Jones, P. D. \& A. Moberg, 2003. Hemispheric and large-scale surface air temperature variations: an extensive revision and an update to 2001. Journal of Climate 16: 206-223.

Jungo, P. \& M. Beniston, 2001. Changes in 20th century extreme temperature anomalies at Swiss climatological stations located at different latitudes and altitudes. Theoretical and Applied Climatology 69: 1-12.

Kapos, V., J. Rhind, M. Edwards, C. Ravilious \& M. Price, 2000. Developing a map of the world's mountain forests. In Price, M. F. \& N. Butt (eds), Forests in a Sustainable Mountain Environment. CAB International, Wallingford.

Keller, F. \& C. Körner, 2003. The role of photoperiodism in alpine plant development. Arctic, Antarctic and Alpine Research 35: 361-368

Kirchofer, W. (eds), 2001. Climate Atlas of Switzerland MeteoSuisse (Swiss Weather Service) publication Zürich, Switzerland:in German and French.

Klötzli, F., 1991. Longevity and stress, Modern Ecology: Basic and Applied Aspects, Esser G. \& Overdiek D., (eds), Elsevier, Amsterdam, 97-110.

Klötzli, F., 1994. Vegetation als Spielball naturgegebener Bauherren. Phytocoenologia 24: 667-675.

Marinucci, M. R., F. Giorgi, M. Beniston, M. Wild, P. Tschuck \& A. Bernasconi, 1995. High resolution simulations of January and July climate over the Western Alpine region with a nested regional modeling system. Theoretical and Applied Climatology 51: 119-138.

Meybeck, M., P. Green \& C. Vörösmarty, 2001. A new typology for mountains and other relief classes: an application to global continental water resources and population distribution. Mountain Research and Development 21: 34-45.
Mountain Agenda. 1998. Mountains of the World. Water Towers for the 21st Century, prepared for the United Nations Commission on Sustainable Development. Institute of Geography, University of Berne (Centre for Development and Environment and Group for Hydrology) and Swiss Agency for Development and Cooperation. Paul Haupt Publishers, Bern, Switzerland, 32 pp.

Myneni, R. B., C. Keeling, C. J. Tucker, G. Asarar \& R. R. Nemani, 1997. Increased plant growth in the northern latitudes from 1981 to 1991 . Nature 386: 698-701.

Nakicenovic, N. et al., 2000. Intergovernmental Panel on Climate Change (IPCC) Special Report on Emission Scenarios. Cambridge University Press, Cambridge, UK and New York, USA, 599.

Ozenda, P., 1985. La Végétation de la Chaine Alpine dans l'Espace Montagnard Européen. Masson, Paris, 344 pp.

Pope, D. V, M. Gallani, R. Rowntree \& A. Stratton, 2000. The impact of new physical parameterizations in the Hadley Centre climate model HadAM3. Climate Dynamics 16: 123-146.

Prock, S. \& Ch. Körner, 1996. A cross-continental comparison of phenology, leaf dynamics and dry matter allocation in arctic and temperate zone herbaceous plants form contrasting altitudes. Ecological Bulletins 45: 93-103.

Quezel, P. \& M. Barbero, 1990. Les forêts méditerranéennes: problèmes posés par leur signification historique, écologique et leur conservation. Acta Botanica Malacitana 15: 145-178.

Rameau, J.C., D. Mansion, G. Dumé, A. Lecointe, J. Timbal, P. Dupont \& R. Keller, 1993. Flore Forestière Française, Guide Ecologique Illustré, Lavoisier TEC and DOC Diffusion, Paris, 2419.

Rotach, M., M. Wild, P. Tschuck, M. Beniston \& M. R. Marinucci, 1997. A double $\mathrm{CO}_{2}$ experiment over the Alpine region with a nested GCM-LAM modeling approach. Theoretical and Applied Climatology 57: 209-227.

Schär, C., P. L. Vidale, D. Lüthi, C. Frei, C. Häberli, M. Liniger \& C. Appenzeller, 2004. The role of increasing temperature variability in European summer heat waves. Nature 427: 332-336.

Schneider, U., 1992. Die Verteilung des troposphärischen Ozons im Bayrischen Nordalpenraum. PhD Dissertation, University of Mainz.

Smidt, S., 1991. Messungen nasser Freilanddepositionen der Forstlichen Bundesversuchsanstalt. FBVA-Berichte, ISSN 1013-0713 50, Nasse Deposition, Austria.

Wade, L. K. \& D. N. McVean, 1969. Mt. Wilhelm studies; The alpine and subalpine vegetation. Australian National University, Canberra, 225 pp.

Wardle, P., 1973. New Zealand timberlines. Arctic and Alpine Research 5: 127-136.

Whiteman, D., 2000. Mountain Meteorology. Oxford University Press, $355 \mathrm{pp}$.

Woodward, F. I., T. M. Smith \& W. R. Emanuel, 1995. A global primary productivity and phytogeography model. Global Biogeochemical Cycles 9: 471-490.

Zorita, E. \& H. Storch, 1999. The analog method - a simple statistical downscaling technique: comparison with more complicated methods. Journal of Climate 12: 2474-2489. 